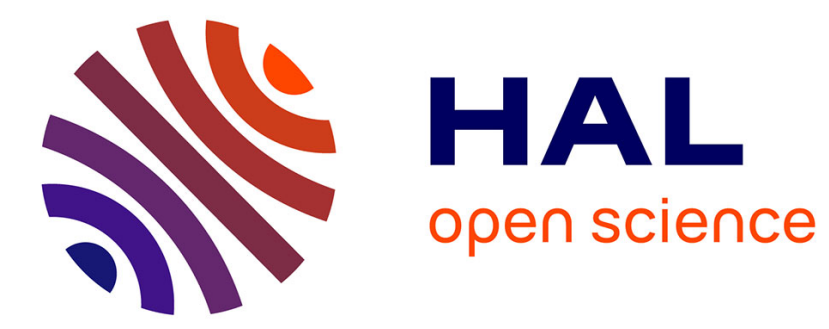

\title{
THE INFLUENCE OF OXYGEN ON THE ELECTRICAL PROPERTIES OF CaF2 AND BaF2 SINGLE CRYSTALS
}

\author{
A. Hammou, M. Duclot, V. Levitskii
}

\section{- To cite this version:}

A. Hammou, M. Duclot, V. Levitskii. THE INFLUENCE OF OXYGEN ON THE ELECTRICAL PROPERTIES OF CaF2 AND BaF2 SINGLE CRYSTALS. Journal de Physique Colloques, 1976, 37 (C7), pp.C7-342-C7-348. 10.1051/jphyscol:1976779 . jpa-00216939

\section{HAL Id: jpa-00216939 https://hal.science/jpa-00216939}

Submitted on 1 Jan 1976

HAL is a multi-disciplinary open access archive for the deposit and dissemination of scientific research documents, whether they are published or not. The documents may come from teaching and research institutions in France or abroad, or from public or private research centers.
L'archive ouverte pluridisciplinaire HAL, est destinée au dépôt et à la diffusion de documents scientifiques de niveau recherche, publiés ou non, émanant des établissements d'enseignement et de recherche français ou étrangers, des laboratoires publics ou privés. 


\title{
THE INFLUENCE OF OXYGEN ON THE ELECTRICAL PROPERTIES OF $\mathrm{CaF}_{2}$ AND $\mathrm{BaF}_{2}$ SINGLE CRYSTALS
}

\author{
A. HAMMOU, M. DUCLOT and V. A. LEVITSKII \\ Laboratoire de Cinétique Electrochimique Minérale, ERA 384 Domaine Universitaire \\ 38401 Saint-Martin-d'Hères, France
}

\begin{abstract}
Résumé. - Le présent travail concerne l'étude de l'influence de l'oxygène sur les propriétés de conduction électrique de $\mathrm{CaF}_{2}$ et $\mathrm{BaF}_{2}$ monocristallins entre 450 et $1200^{\circ} \mathrm{C}$. Trois types d'étude ont été entrepris : thermogravimétrie, conductivité électrique totale et nombre de transport cationique. Les résultats montrent que l'oxygène se place en position substitutionnelle. La réaction d'introduction s'accompagne de l'apparition de lacunes d'ions fluorure $V_{F}$ et d'un départ irréversible de fluor. L'étude a permis de suivre l'évolution des domaines intrinsèque, extrinsèque et d'association en fonction de la pression partielle d'oxygène.
\end{abstract}

Abstract. - This work covers the study of the influence of oxygen on the electrical conductivity of $\mathrm{CaF}_{2}$ and $\mathrm{BaF}_{2}$ single crystals for the temperature range $450-1200^{\circ} \mathrm{C}$. The study included three different aspects : thermogravimetry measurements, total electrical conductivity and cationic transport number. Results show that oxygen takes up substitutional positions. The reaction of introduction is accompanied by the occurrence of fluoride ion vacancies, $V_{F}^{\circ}$, and the irreversible departure of fluorine. The study also showed how the intrinsic, extrinsic and association domains vary according to the partial pressure of oxygen.

1. Introduction. - The study of charge and matter transport phenomena in halides of fluorite structure has been mainly centered on alkali-earth fluorides, of formula $\mathrm{MF}_{2}(\mathrm{M}=\mathrm{Ca}, \mathrm{Ba}, \mathrm{Sr})$ and on solid solutions of the type $\mathrm{MF}_{2}-\mathrm{M}^{\prime} \mathrm{F}\left(\mathrm{M}^{\prime}=\mathrm{Na}, \mathrm{K}\right)$ and $\mathrm{MF}_{2}-\mathrm{M}^{\prime \prime} \mathrm{F}_{3}$ $\left(M^{\prime \prime}=\right.$ rare earth) [1 to 16$]$. It has shown that :

- Conductivity is purely ionic over a wide range of fluorine partial pressures. Current transport is ensured exclusively by the fluoride ions following an interstitial or vacancy mechanism.

- The doping fluoride cations take up substitutional positions. The electric charge is compensated by the occurrence of fluoride ion vacancies $V_{\vec{F}}$ or interstitial fluoride ions, $F_{i}^{\prime}$.

The dominating phase disorder is most probably of the anti-Frenkel type.

By measuring total electrical conductivity versus temperature, three domains characteristic of intrinsic, extrinsic and association behaviour in the material were identified.

The ionic character of conductivity in alkali-earth fluorides, and especially in calcium fluoride, makes them suitable for use as a solid electrolyte in galvanic cells for thermodynamic measurements. For instance, the following chain was used by Wagner [17] to define the activity of calcium oxide in calcium silicate :

$\mathrm{O}_{2}, \mathrm{Pt} / \mathrm{CaO}, \mathrm{CaF}_{2} / \mathrm{CaF}_{2} / \mathrm{CaSiO}_{3}, \mathrm{SiO}_{2}, \mathrm{CaF}_{2} / \mathrm{Pt}, \mathrm{O}_{2}$.
For this type of measurement, the redox stability range of the solid electrolyte used must be known. There must be no risk of a reaction likely to modify the electrolyte or to give rise to electronic conductivity. In the chain described above, the chemical potential of the oxygen must be firmly established. This leads one to enquire about the influence of oxygen on the type of conduction in the fluoride. This paper attempts to provide an answer.

2. Experimental methods and results. - The experiments are carried out on single crystals obtained by the Czochralski method in an oxygen-free atmosphere.

2.1 THERMO-GRAVIMETRIC MEASUREMENTS. - Results of thermo-gravimetric measurements carried out mainly on $\mathrm{CaF}_{2}$ at temperatures of between 1040 and $1100^{\circ} \mathrm{C}$, lead to the following conclusions :

- no variation in weight is recorded in inert atmosphere,

in oxygen, the higher the temperature, the more rapid the loss in weight of the sample.

2.2 Measurement of total electrical CONDUCTIVITY. - The experimental apparatus used for the measurement of total electrical conductivity has been described elsewhere [18]. The complex impedance diagram method was systematically adopted [19]. Under certain conditions, this enables conductivity and 
dielectric polarisation phenomena specific to the material to be distinguished from those associated with polarisation phenomena at the electrodes. This distinction can be made by varying several parameters influencing either the electrolyte, that is, the length $l$ and the geometrical factor $K=l / S(S=$ cross-section area of the sample), or the electrodes, that is, the current density, the nature of the electrode, its texture, etc...

2.2.1 General features of the complex impedance diagrams obtained. - Figure 1 illustrates the different types of diagrams obtained over the whole range of temperature and oxygen partial pressure investigated.

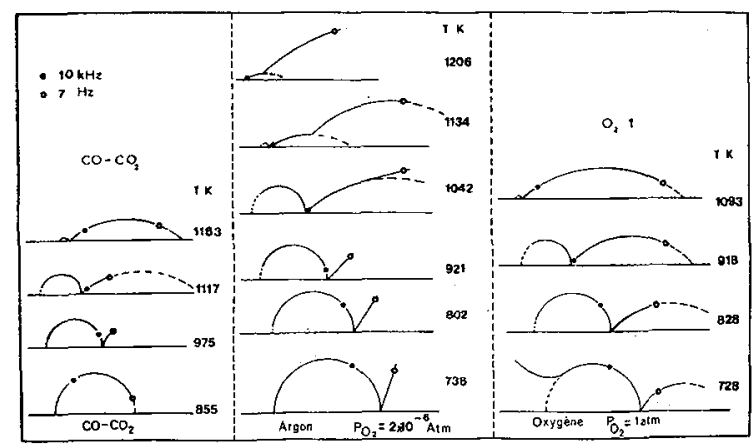

FIG. 1. - Different types of complex impedance diagrams obtained with $\mathrm{CaF}_{2}$.

For instance, figure 2 shows diagrams that are representative of results obtained on $\mathrm{BaF}_{2}$. The characteristic points are the intersections, $R_{1}$ and $R_{2}$, of the arcs obtained at high frequencies with the real axis. Tables I and II compare the ratios of the geometrical factors of samples of $\mathrm{CaF}_{2}$ and $\mathrm{BaF}_{2}$, respectively, with those of $R_{1}, R_{2}$ and $R_{2}-R_{1}$. For all the samples, only $R_{2}$ satisfactorily follows the relationship existing between the electrical resistance of a conductor and its geometrical characteristics. $R_{2}$ is therefore clearly the resistance of the material studied, and can be used to acquire the total conductivity $\sigma_{t}$.

2.2.2 Variation of the function $\log \sigma_{1} T=f(1 / T)$ versus the partial pressure of oxygen. - In this type of study, measurements must always be carried out starting with low partial pressures of oxygen (mixtures of $\mathrm{CO}-\mathrm{CO}_{2}$ ) and going on to intermediate pressures (mixtures of argon-oxygen) then to high pressures (pure oxygen). The results for $\mathrm{CaF}_{2}$ and $\mathrm{BaF}_{2}$ are given on figures 3 and 4 respectively. Total conductivity is shown to increase with increasing partial pressure of oxygen. In general, four different domains, A, B, C and $D$ can be identified in the temperature range investigated. The corresponding activation energies are given in table III and IV It is interesting to note that the transition from domain $\mathrm{B}$ to domain $\mathrm{C}$ is conti-
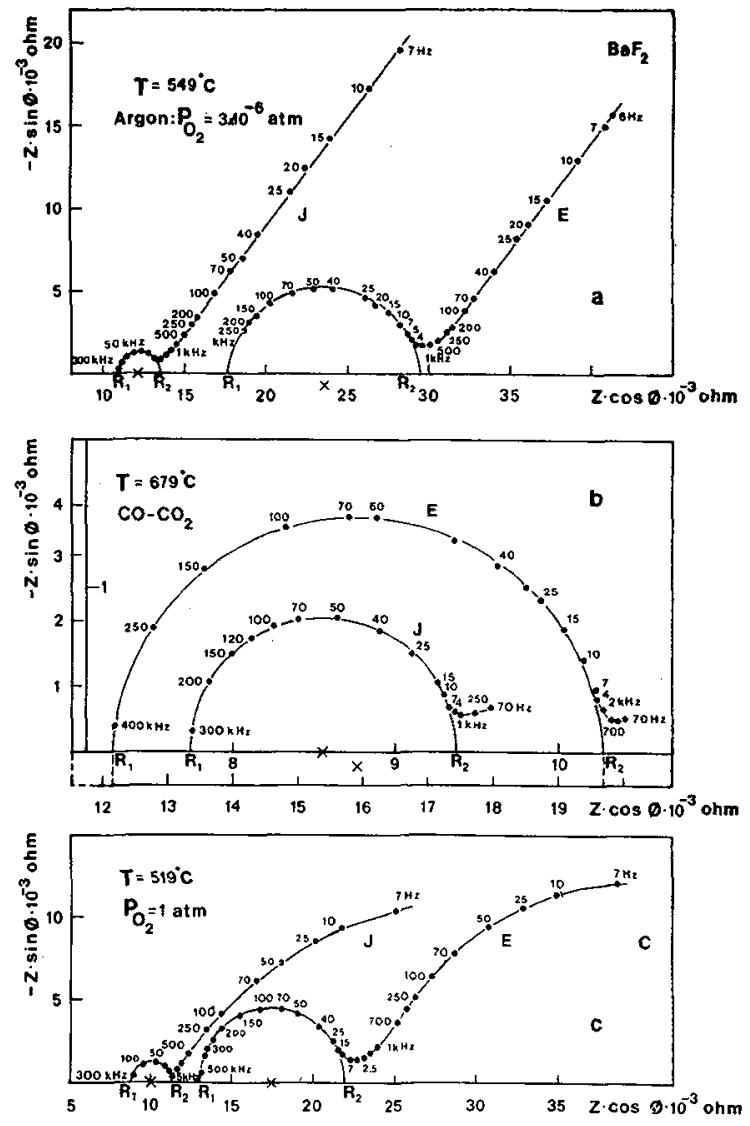

Frg. 2. - Complex impedance diagrams for $\mathrm{BaF}_{2}$ in :a) argon at $\left.549^{\circ} \mathrm{C} ; b\right) \mathrm{CO}-\mathrm{CO}_{2}$ at $679^{\circ} \mathrm{C} ; c$ ) oxygen at $519^{\circ} \mathrm{C}$.

nuous and spread out over a temperature range of the order of about $120^{\circ} \mathrm{C}$.

In order to identify any possible electronic conductivity due to the introduction of oxygen in the lattice, the resistance of the samples was measured again in decreasing order of oxygen partial pressures. Results obtained for $\mathrm{CaF}_{2}$ and $\mathrm{BaF}_{2}$ respectively are shown in figures 5 and 6 . No variation was observed that could be interpreted as electronic conduction.

2.3 Study of Cationic tRANSPORT. - The cationic transport number is measured by the expansioncoulometry method [20,21]. Figures 7 and 8 illustrate the variation in the cationic transport number versus temperature for $\mathrm{CaF}_{2}$ and $\mathrm{BaF}_{2}$, respectively. Variations in cationic conductivity $\left(\sigma_{\text {cat }}\right)$ (cf. Figs. 9 and 10) are obtained from total electrical conductivity by the equation :

$$
\sigma_{\mathrm{cat}}=\sigma_{\mathrm{t}} \cdot t_{\mathrm{cat}}
$$

where $t_{\mathrm{cat}}$ is the cationic transport number. These results show that cationic conductivity is negligible compared with total conductivity. Using the NernstEinstein equation, the self-diffusion coefficients of barium in $\mathrm{BaF}_{2}$ and calcium in $\mathrm{CaF}_{2}$ were calculated. The results are in good agreement with the literature [2], [7], [22] to [24]. The activation energies eva- 
TABLe I

Comparison of the ratios of the geometrical factors of samples of $\mathrm{CaF}_{2}$ with those of $R_{1}, R_{2}$ and $R_{2}-R_{1}$

$\begin{array}{cccccc}t^{\circ} \mathrm{C} & K=\frac{K_{\mathrm{C}}}{K_{\mathrm{H}}} & \frac{\left(R_{2}\right)_{\mathrm{C}}}{\left(R_{2}\right)_{\mathrm{H}}} & \frac{\left(R_{1}\right)_{\mathrm{C}}}{\left(R_{1}\right)_{\mathrm{H}}} & \frac{\left(R_{2}-R_{1}\right)_{\mathrm{C}}}{\left(R_{2}-R_{1}\right)_{\mathrm{H}}} & \text { Atmosphere } \\ - & - & -13 \pm 0.09 & 1.18 \pm 0.05 & 2.27 \pm 0.10 & - \\ 512 & 2.13 & 2.16 & 1.29 \pm 0.05 & 2.51 \pm 0.13 & \\ 551 & 2.13 & 2.24 \pm 0.09 & 1.97 \pm 0.08 & 2.27 \pm 0.14 & \text { CO-CO }_{2} \\ 592 & 2.13 & 2.18 \pm 0.09 & 1.68 \pm 0.07 & 2.78 \pm 0.26 & \\ 630 & 2.13 & 2.22 \pm 0.09 & 1.77 \pm 0.07 & 3.18 \pm 0.05 & \\ 679 & 2.13 & 2.22 \pm 0.09 & 1.61 \pm 0.07 & 3.1 \pm 0.3 & \\ 478 & 2.13 & 2.26 \pm 0.10 & 1.65 \pm 0.07 & 3.0 \pm 0.3 & \\ 496 & 2.13 & 2.27 \pm 0.10 & 1.64 \pm 0.07 & 3.9 \pm 0.6 & \\ 648 & 2.13 & 2.22 \pm 0.09 & 1.66 \pm 0.07 & 4.6 \pm 1.0 & \\ 660 & 2.13 & 2.24 \pm 0.09 & 1.78 \pm 0.08 & 4.9 \pm 1.4 & \\ 700 & 2.13 & 2.24 \pm 0.08 & 2.21 \pm 0.10 & & \\ 861 & 2.13 & 2.27 \pm 0.10 & 2.21 & \\ 900 & 2.13 & 2.23 \pm 0.09 & 2.23 \pm 0.09 & & \\ 933 & 2.13 & 2.24 \pm 0.09 & 2.24 \pm 0.09 & & \end{array}$

TABLE II

Comparison of the ratios of the geometrical factors of samples of $\mathrm{BaF}_{2}$ with those of $R_{1}, R_{2}$ and $R_{2}-R_{1}$

\begin{tabular}{|c|c|c|c|c|c|}
\hline $\begin{array}{l}t^{\circ} \mathrm{C} \\
-\end{array}$ & $K=\frac{K_{\mathrm{E}}}{K_{\mathrm{J}}}$ & $\frac{\left(R_{2}\right)_{\mathrm{E}}}{\left(R_{2}\right)_{\mathrm{J}}}$ & $\frac{\left(R_{1}\right)_{\mathrm{E}}}{\left(R_{1}\right)_{\mathrm{J}}}$ & $\frac{\left(R_{2}-R_{1}\right)_{\mathrm{E}}}{\left(R_{2}-R_{1}\right)_{\mathrm{J}}}$ & $\begin{array}{c}\text { Atmosphere } \\
-\end{array}$ \\
\hline 454 & $2.150 \pm 0.005$ & $2.12 \pm 0.09$ & $1.74 \pm 0.05$ & $5.4 \pm 0.1$ & \\
\hline 554 & 2.150 & $2.11 \pm 0.09$ & $1.57 \pm 0.05$ & $6.4 \pm 0.14$ & \\
\hline 630 & 2.150 & $2.12 \pm 0.09$ & $1.54 \pm 0.05$ & $5.4 \pm 0.3$ & $\mathrm{CO}-\mathrm{CO}_{2}$ \\
\hline 679 & 2.15 & $2.10 \pm 0.09$ & $1.57 \pm 0.05$ & $4.6 \pm 0.4$ & \\
\hline 463 & 2.15 & $2.12 \pm 0.08$ & $1.44 \pm 0.06$ & $4.6 \pm 0.1$ & \\
\hline 529 & 2.15 & $2.18 \pm 0.08$ & $1.58 \pm 0.06$ & $4.8 \pm 0.2$ & $\mathrm{Ar}$ \\
\hline 648 & 2.15 & $2.14 \pm 0.09$ & $1.66 \pm 0.06$ & $4.3 \pm 0.3$ & \\
\hline 556 & 2.15 & $2.10 \pm 0.09$ & $1.51 \pm 0.05$ & $3.56 \pm 0.1$ & \\
\hline 780 & 2.15 & $2.16 \pm 0.09$ & - & - & \\
\hline 820 & 2.15 & $2.16 \pm 0.09$ & - & 一 & $\mathrm{O}_{2}$ \\
\hline 919 & 2.15 & $2.11 \pm 0.09$ & - & - & \\
\hline 946 & 2.15 & $2.10 \pm 0.09$ & 一 & - & \\
\hline
\end{tabular}




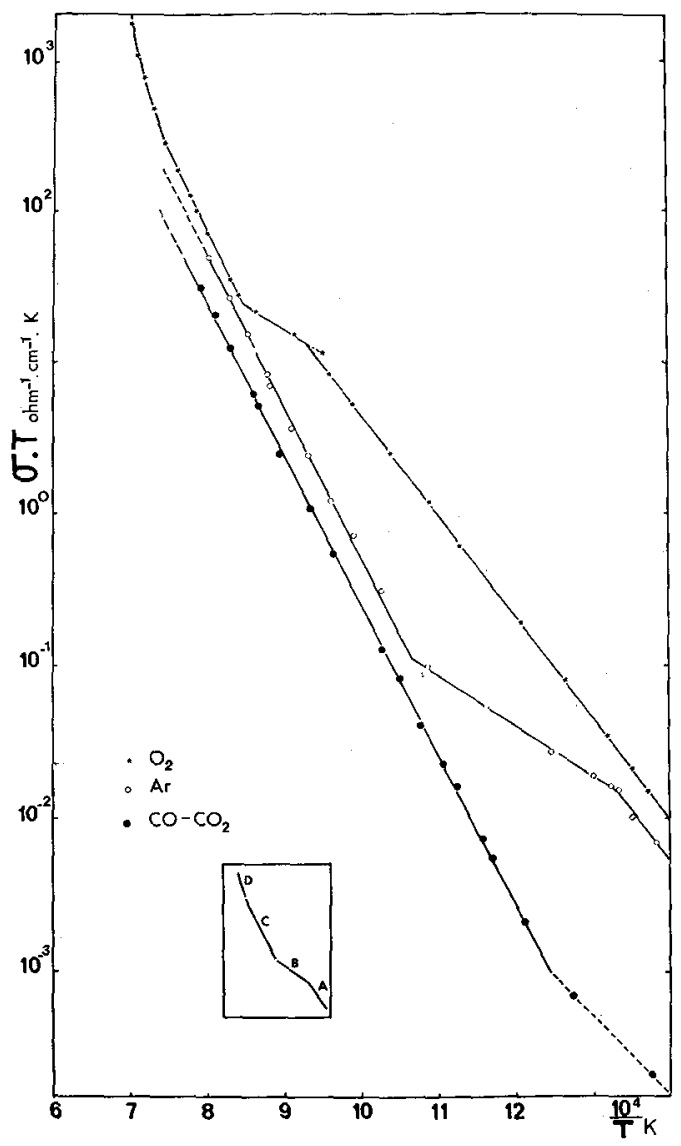

FIG. 3. - Variation of the function $\log \sigma_{t} T=f(1 / T)$ for $\mathrm{CaF}_{2}$.

\section{TABLE III}

Values of the migration energy $E_{\mathrm{m}}$, formation energy, $E_{\mathrm{f}}$, of the anti-Frenkel pair, and the association energy, $E_{\text {ass. }}$ in $\mathrm{CaF}_{2}$

\begin{tabular}{|c|c|c|c|c|c|c|}
\hline \multirow[t]{2}{*}{$E \mathrm{eV}$} & \multicolumn{3}{|c|}{$E$ experimental } & \multirow{2}{*}{$E_{\mathrm{m}_{\mathbf{V}} \dot{\boldsymbol{F}}}$} & \multirow{2}{*}{$E_{\mathfrak{q}}$} & \multirow{2}{*}{$E_{\text {ass. }}$} \\
\hline & $E_{\text {intr. }}$ & $E_{\text {extr. }}$ & $E_{\text {assoc. }}$ & & & \\
\hline $\mathrm{CO}-\mathrm{CO}_{2}$ & 2.0 & - & 一 & - & 2.56 & 一 \\
\hline Ar & 2.0 & 0.63 & 1.30 & 0.63 & 2.7 & -1.3 \\
\hline $\mathrm{O}_{2}$ & 2.1 & 0.64 & 1.30 & 0.64 & 2.9 & -1.3 \\
\hline
\end{tabular}

luated at 3.9 and $3.3 \mathrm{eV}$ in $\mathrm{CaF}_{2}$ and $\mathrm{BaF}_{2}$, respectively, do not provide sufficient evidence of the type of dominating disorder in the cationic sub-lattice. However, they do suggest that the cationic transport mechanism is identical in both materials.

3. Discussion. - 3.1 EXPLANATION OF THE MECHANISM OF OXYGEN INTRODUCTION. - The experimental data show that total electrical conductivity of alkaliearth fluorides increases with the increase in partial

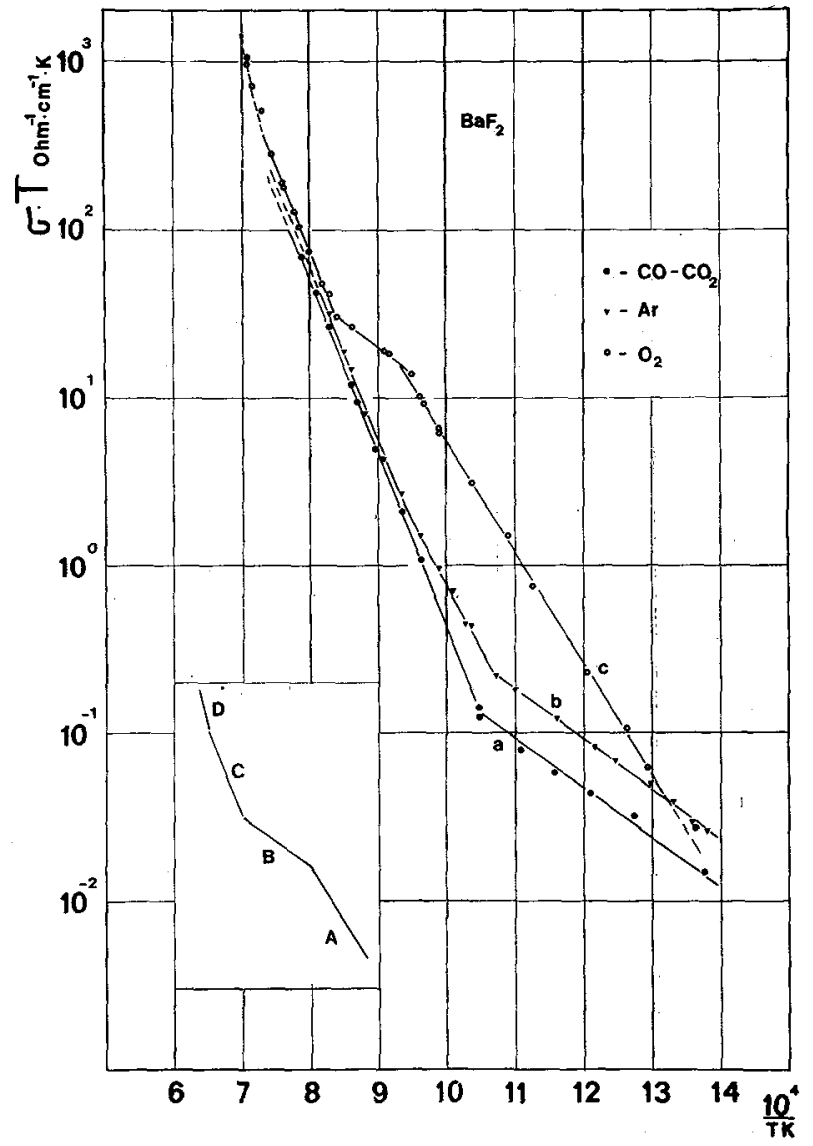

Fig. 4. - Variation of the function $\log \sigma_{\mathrm{t}} T=f(1 / T)$ for $\mathrm{BaF}_{2}$.

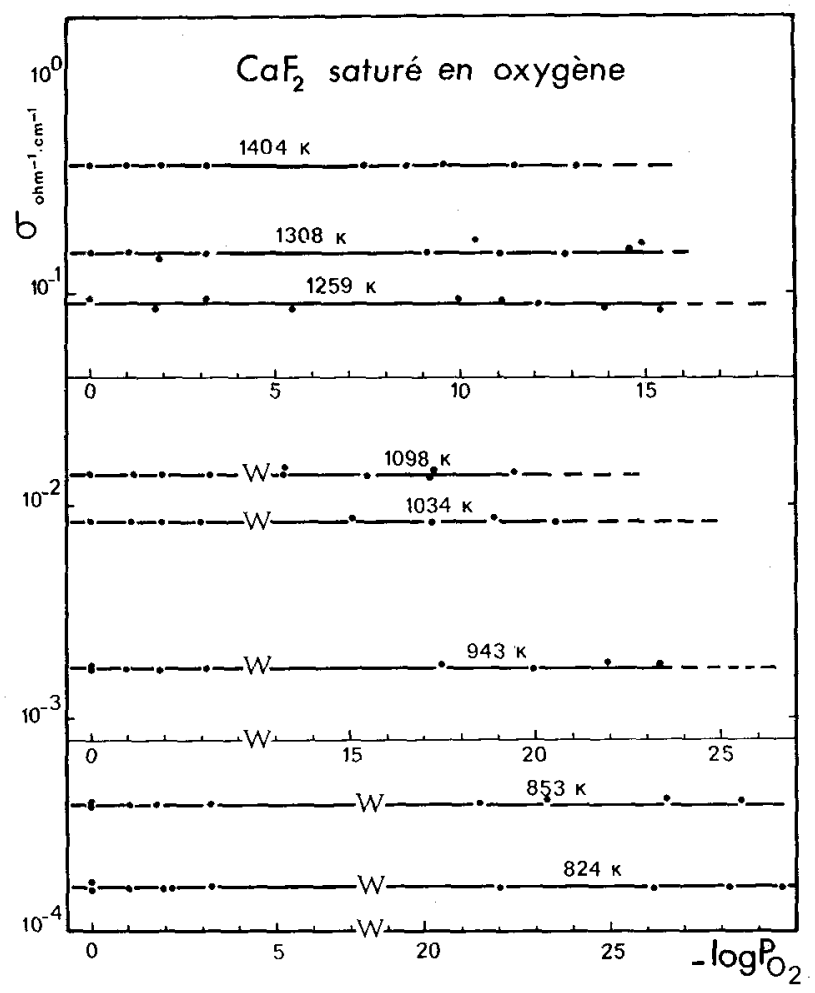

FIG. 5. - Variation of total conductivity of oxygen- saturated $\mathrm{CaF}_{2}$ versus oxygen partial pressure. 


\section{TABLE IV}

Values of the migration energy $E_{\mathrm{m}}$, formation energy, $E_{\mathrm{f}}$, of the anti-Frenkel pair, and the association energy, $E_{\text {ass. }}$ in $\mathrm{BaF}_{2}$

\begin{tabular}{|c|c|c|c|c|c|c|c|c|c|c|}
\hline \multirow{3}{*}{$\begin{array}{l}E \mathrm{eV} \\
\text { Atm. }\end{array}$} & \multicolumn{6}{|c|}{$E_{\text {exprimental }}$} & \multirow{3}{*}{$E_{\mathbf{m}_{\mathbf{v}} \dot{\boldsymbol{F}}}$} & \multirow{3}{*}{$E_{\mathrm{l}}$} & \multirow{3}{*}{$E_{\text {ass. }}$} & \multirow{3}{*}{ Ref. } \\
\hline & \multicolumn{2}{|c|}{ Intrinsic } & \multicolumn{2}{|c|}{ Extrinsic } & \multicolumn{2}{|c|}{ Association } & & & & \\
\hline & $E$ & $T^{\circ} \mathrm{C}$ & $E$ & $T^{\circ} \mathrm{C}$ & $E$ & $T^{\circ} \mathrm{C}$ & & & & \\
\hline $\mathrm{CO}-\mathrm{CO}_{2}$ & $2.07 \pm 0.03$ & $680-990$ & $0.59 \pm 0.03$ & $680-440$ & 一 & - & $0.59 \pm 0.03$ & $2.96 \pm 0.08$ & - & $\begin{array}{c}\text { Present } \\
\text { work }\end{array}$ \\
\hline Ar & $\begin{array}{c}1.64 \\
1.64\left(^{*}\right) \\
2.06 \pm 0.04\end{array}$ & $\mid \begin{array}{l}620-900 \\
- \\
795-1065\end{array}$ & $\begin{array}{c}0.85 \\
0.56^{*} \\
\overline{0} \\
0.59 \pm 0.02\end{array}$ & $\begin{array}{c}T<620 \\
660-440\end{array}$ & $\begin{array}{c}1 . \overline{24}\left(^{*}\right) \\
-\end{array}$ & - & $\begin{array}{c}0.85 \\
0.56^{*} \\
0.37 \\
0.59 \pm 0.02\end{array}$ & $\begin{array}{c}1.6-1.8 \\
\left.1.9^{*}\right) \\
2.3^{*} \\
2.94 \pm 0.10\end{array}$ & $\begin{array}{c}1.36(*) \\
-\end{array}$ & $\begin{array}{c}(9) \\
(8) \\
(10) \\
\text { Present } \\
\text { work }\end{array}$ \\
\hline $\mathbf{O}_{2}$ & $2.08 \pm 0.08$ & $920-1065$ & $0.63 \pm 0.02$ & $920-800$ & $1.32 \pm 0.02$ & $T<800$ & $0.63 \pm 0.02$ & $2.90 \pm 0.16$ & $1.38 \pm 0.03$ & $\begin{array}{c}\text { Present } \\
\text { work }\end{array}$ \\
\hline
\end{tabular}

(*) $\mathrm{BaO}$ doped $\mathrm{BaF}_{2}$.

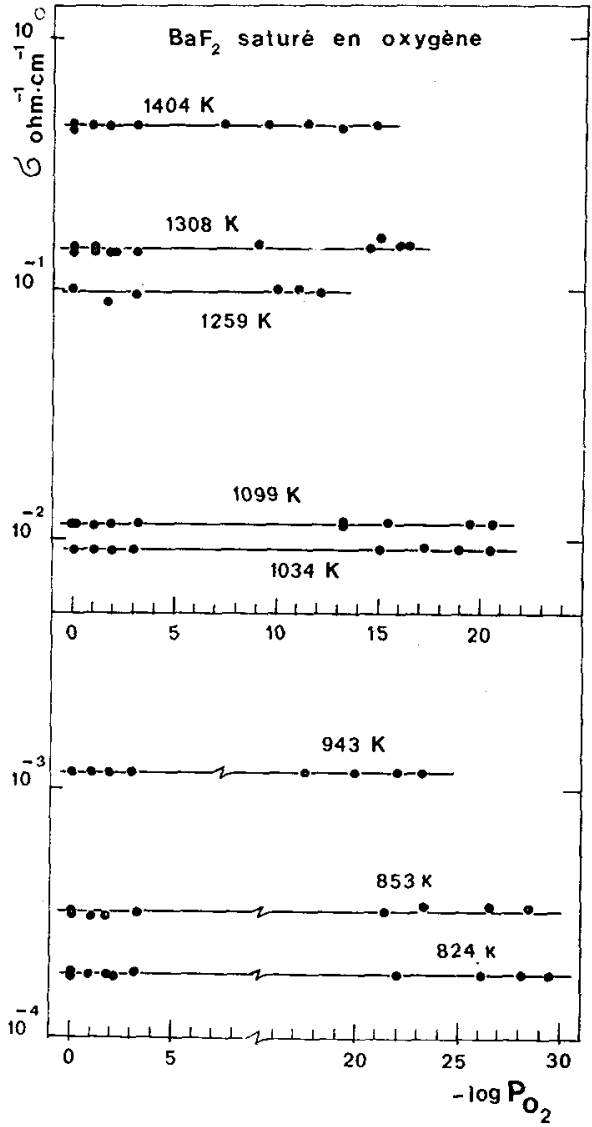

FIG. 6. - Variation of total conductivity of oxygen- saturated $\mathrm{BaF}_{2}$ versus oxygen partial pressure.

pressure of oxygen. Several mechanisms can be suggested to explain the effect of this introduction of oxygen in the crystal lattice. Some involve electronic species able

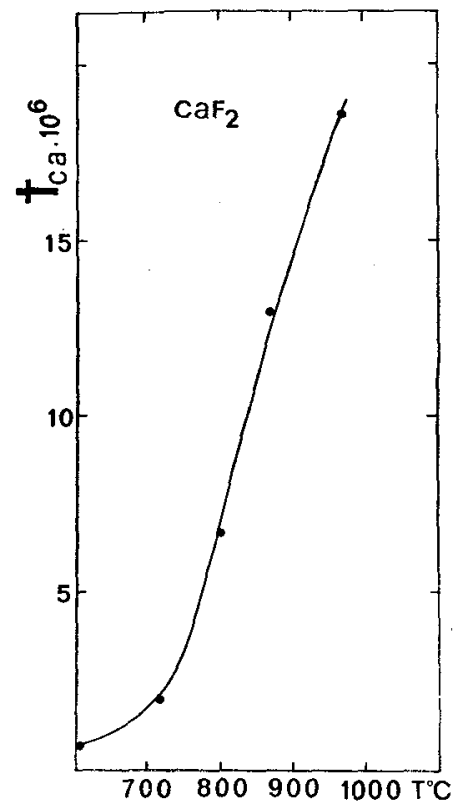

FIG. 7. - Variation of the cationic transport number versus temperature in $\mathrm{CaF}_{2}$.

to induce an electronic type conduction. Measurements on the thermobalance indicate a loss in weight of the sample in the presence of oxygen. The most likely hypothesis to explain this behaviour is the irreversible departure of fluorine. Possible reactions are the following :

$$
\begin{aligned}
& \frac{1}{2} \mathrm{O}_{2}+\mathrm{F}_{\mathrm{F}}^{\mathrm{x}} \rightarrow \mathrm{O}_{\mathrm{F}}^{\prime}+\mathrm{h}^{\cdot}+\frac{1}{2} \mathrm{~F}_{2} \\
& \frac{1}{2} \mathrm{O}_{2}+2 \mathrm{~F}_{\mathrm{i}}^{\prime} \rightarrow \mathrm{O}_{\dot{\mathrm{i}}}^{\prime \prime}+\mathrm{F}_{2} \\
& \frac{1}{2} \mathrm{O}_{2}+2 \mathrm{~F}_{\mathrm{F}}^{\mathrm{x}} \rightarrow \mathrm{V}_{\mathrm{F}}^{\prime}+\mathrm{O}_{\mathrm{F}}^{\prime}+\mathrm{F}_{2}
\end{aligned}
$$




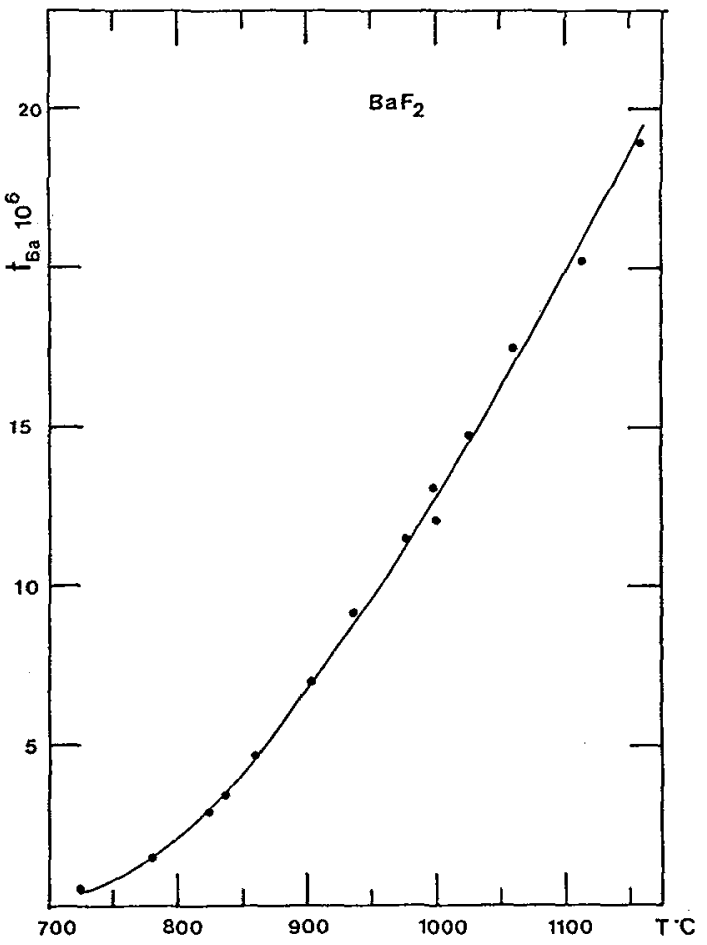

FIG. 8. - Variation of the cationic transport number versus temperature in $\mathrm{BaF}_{2}$.

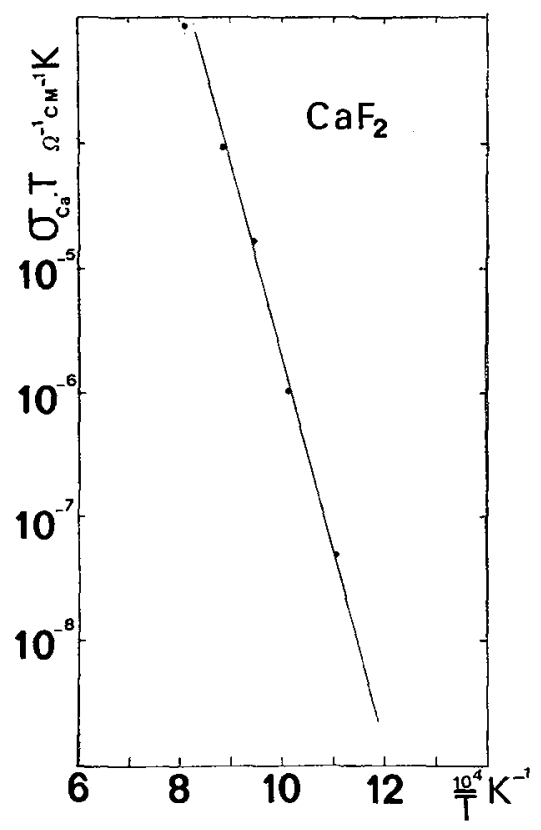

FIG. 9. - Variation of the function $\log \sigma_{\mathrm{cat}} T=f(1 / T)$ for $\mathrm{CaF}_{2}$.

Reaction $(a)$ is not satisfactory since it shows an electronic type conduction with a theoretical dependence on oxygen partial pressures that is not in agreement with experimental results, for whatever temperature range considered.

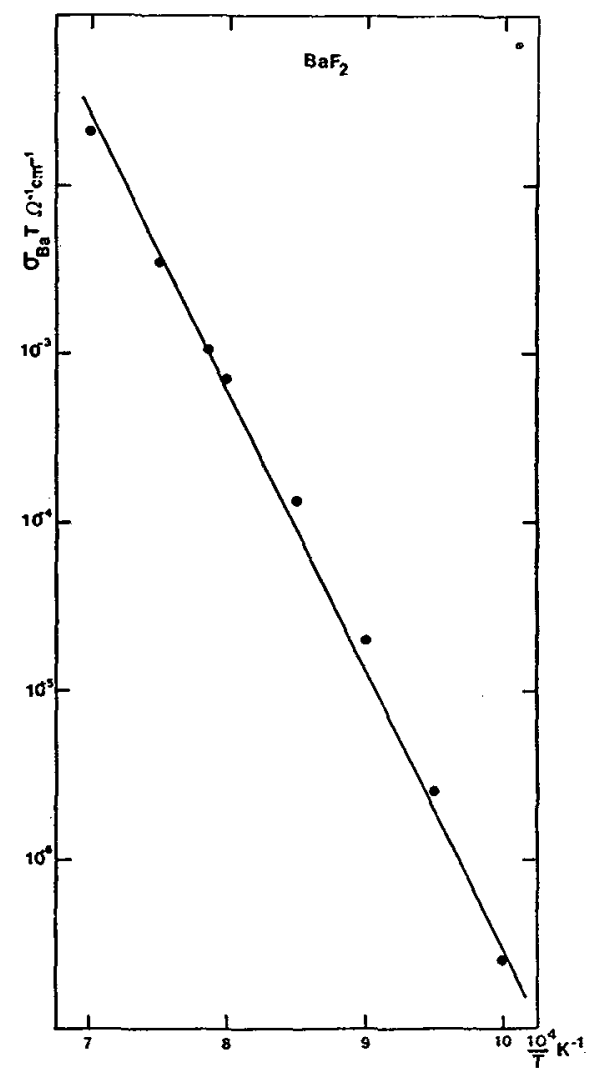

FIG. 10. - Variation of the function $\log \sigma_{\mathrm{cat}} T=f(1 / T)$ for $\mathrm{BaF}_{2}$.

Reaction $(b)$ involves only ionic species. If the fluoride ions and oxide ions are assumed to have similar mobilities, resulting from an identical interstitial mechanism, the conduction balance will show a decrease in conduction.

In contrast, reaction $(c)$ shows an increase in the number of fluoride ion vacancies $V_{F}^{*}$ which explains the increase in total conductivity as well as its ionic character.

3.2 IDENTIFICATION OF THE DOMAINS ON THE CURVES $\log \sigma_{t} T=f(1 / T)$. - Each of the domains A, B, C and $D$ observed on the curves shown on figures 3 and 4 is characteristic of a specific behaviour of the material.

Domain $B$, in which activation energy is the lowest, corresponds to an extrinsic behaviour. It is characterized by the activation energy $E_{\mathrm{m}}$ which expresses the enthalpy of the fluoride ion migration by a vacancy mechanism. This activation energy seems to increase with the partial pressure of oxygen. This would suggest that the activation energy is a function of the oxide ion content in the crystal.

Domain $\mathrm{C}$ characterizes the intrinsic behaviour of the material and leads to the value of the formation energy $E_{\mathrm{f}}$ of an anti-Frenkel pair $\left(\mathrm{V}_{\mathrm{F}}^{*}+\mathrm{F}_{\mathrm{i}}^{\prime}\right)$.

Domain $\mathrm{D}$ concerns temperatures above approximately $1100^{\circ} \mathrm{C}$. Here there is a rapid increase in conductivity. It is very difficult to deduce an activation 
energy characterizing any possible formation of new species or the occurrence of new transport mechanisms. This behaviour may be due, on the one hand, to an increase in the concentration of vacancies, $V_{F}^{*}$ of extrinsic origin which becomes no longer negligible compared with that of intrinsic origin. It may be due, on the other hand, to the presence of other species contributing to the transport, such as interstitial fluoride ions $F_{i}^{\prime}$ and probably oxide ions $O_{F}^{\prime}$.

Finally, domain A characterizes the association zone. It only occurs in observable form in pure oxygen. The association reaction mainly involves the species $V_{F}^{*}$ and $\mathrm{O}_{\mathrm{F}}^{\prime}$.

The values of the migration energy $E_{\mathrm{m}}$, the formation energy of the anti-Frenkel pair, $E_{\mathrm{f}}$, and the association energy, $E_{\text {ass., for }} \mathrm{CaF}_{2}$ and $\mathrm{BaF}_{2}$ are shown on table IV, respectively. The values are in good agreement with those given in the literature [4], [10], [8].

4. Conclusion. - This work helps to understand the influence of oxygen on the electrical properties of $\mathrm{CaF}_{2}$ and $\mathrm{BaF}_{2}$ single crystals. In particular, it has shown that total conductivity increases with an increase in the partial pressure of oxygen. This behaviour is due to the introduction of oxygen into the material. When oxygen is introduced, this does not give rise to an electronic type conductivity but to an increase in the number of fluoride ion vacancies of extrinsic origin, while the oxide ions take up substitutional positions, $\mathrm{O}_{\mathrm{F}}^{\prime}$.

\section{References}

[1] URE, R. W., J. Chem. Phys. 26 (1975) 1363.

[2] Berard, M. F., J. Amer. Ceram. Soc. 54 (1971) 144.

[3] MatzKe, H., J. Mater. Sci. 5 (1970) 831.

[4] Bollmann, W., Gorlich, P., Ank, W., Mothes, H., Phys. Status Solidi 2 (1970) 157

[5] WAGNER, C., J. Electrochem. Soc. 115 (1968) 933.

[6] Hinze, J. W., Patterson, J. W., J. Electrochem. Soc. 120 (1973).

[7] Barker, M., Taylor, A., J. Phys. \& Chem. Solids, 30 (1969) 1003.

[8] Barsis, E., Taylor, A., J. Chem. Phys. 48 (1968) 4357.

[9] Barsis, E., Taylor, A., J. Chem. Phys. 45 (1966) 1154.

[10] Catlow, C. R. A., Norgett, M. J., J. Phys. C. : Solid State Phys. 6 (1973) 465.

[11] Frankln, A. D., in Point Defects in Solids, Volume 1, General and Ionic Crystals (1972) 1-101.

[12] NAGEL, L. E., O'KeEFFe, M., in Fast Ion Transport in Solids, W. van Gool ed. (North Holland Publ. Co) 1972, 165-171.
[13] Fong, F. K., Progress in Solid State Chem. 3 (1967) 135.

[14] Derrington, C. E., Lindner, A., O'Keeffe, M., J. Solid State Chem. 15 (1975) 171.

[15] Reau, J. M., Lucat, C., Campet, G., Portier, J., HamMoU, A., J. Solid State Chem. (1976).

[16] Levitskin, V., Hammou, A., Duclot, M., Deportes, C., J. Chim. Phys. 73 (1976) 305.

[17] Wagner, C., J. Phys. Chem. 49 (1966) 38-43.

[18] Hammou, A., Deportes, C., Robert, G., J. Chim. Phys. 7-8 (1971) 1162.

[19] Baurerle, J. E., J. Phys. \& Chem. Solids 30 (1969) 2657.

[20] Deportes, C., Gauthier, M., C. R. Hebd. Séan. Acad. Sci. 273 (1971) 1605

[21] Gauthier, M., Duclot, M., Hammou, A., Deportes, C., J. Solid State Chem. 9 (1974) 15.

[22] Matzke, M., Lindner, R., Z. Naturforsch. A 19 (1964) 1178.

[23] Short, J. M., Roy, R., J. Phys. Chem. 68 (1964) 3077.

[24] King, A. D., Moerman, H., Phys. Status Solidi (a) 22 (1974) 455.

\section{DISCUSSION}

A. V. Chadwick. - It is not sufficient to compare the activation energies of the conductivity plots from various studies. Have you compared the absolute magnitude of your conductivity data with that of previous workers ? Also what is the predicted conductivity at the melting point from your results ?

A. Hammou. - We can compare the values of electrical conductivity with sufficient accuracy only in the intrinsic domain at sufficiently high temperature. Concerning your second question, the predicted value at the melting point, for $\mathrm{BaF}_{2}$, in inert atmosphere, is equal to $0.92 \Omega^{-1} \mathrm{~cm}^{-1}$. It is an extrapolated value but certainly not the true. 